\title{
Trends of Development of International Water Law
}

\author{
Paulo Canelas de Castro \\ Faculty of Law, University of Macau, Macau, China \\ Email: pcanelas@umac.mo
}

Received 29 September 2015; accepted 4 December 2015; published 7 December 2015

Copyright (c) 2015 by author and Scientific Research Publishing Inc.

This work is licensed under the Creative Commons Attribution International License (CC BY).

http://creativecommons.org/licenses/by/4.0/

(c) (i) Open Access

\begin{abstract}
International water law has been witnessing profound changes in the latter twenty years. These changes denote certain cardinal options for new goals and values that the newer international water law is seeking to embrace. Amongst these new goals and values, the ones of environmentalization, humanisation, economicisation stand out as attempts at bringing efficient response to the challenges set by the current global water crisis and the more complex expectations of the international community. They amount to an innovative normative message and even true paradigmshifts in the understanding of international water law. These trends of development of international water law set this legal field in line with other chapters of contemporary international law and derive in part from the cross-fertilisation of normative ideas and principles between these chapters of international law.
\end{abstract}

\section{Keywords}

Economicisation, Environmentalization, Global Water Crisis, Humanisation, Human Right to Water, International Water Law, Paradigm Changes, Trade in Water, Water Protection, Water Services

\section{Introduction}

After a few decades of a rather lethargic state, corresponding to the attempt at codifying it—undertaken, particularly, by the International Law Commission ${ }^{1,2}$, and marked by a rather schizophrenic debate over the prevalence of two water sharing principles ${ }^{3}$, simplistically seen as competing: those of the equitable and reasonable use of international watercourses and the obligation not to cause damage, also known as the no harm prin${ }^{1}$ See Tanzi \& Arcari, 2001, and McCaffrey, 2007. The Law of International Watercourses-Non-navigational Uses, Oxford: Oxford University Press, $2^{\text {nd }}$ ed., 2007.

${ }^{2}$ Prior to the International Law Commission's effort, the same concern had already led the International Law Association to adopt in 1966 the Rules on the Uses of the Waters for International Rivers, usually known as "the Helsinki Rules". They deal with navigational as well as non-navigational uses of rivers. See International Law Association, 1967. See also Manner \& Metsalampi (eds.), $1988 ;$ Bogdanovic, 2001.

${ }^{3}$ For the understanding of these principles prior to the adoption of the United Nations Watercourses Convention, see e.g., Caflisch, 1993. 
ciple-International Water Law has been witnessing a considerable normative development in the latter two decades.

This normative development may be detected in multiple signs. Foremost, in the frantic law-making endeavors permeating international life: most noticeably, those translated in the adoption of numerous treaties at the different ambits of the international society ${ }^{4}$; but also in, the not less significant, soft law ${ }^{5}$, undertaken in particular by manifold international organizations or conferences, which, in the period, have brought water issues to the forefront of the global international agenda. Additionally, also in the several international disputes where water is invoked as the main subject-matter and the unprecedented swathe of decisions which take water and international water law as their casus decidendi and rationale ${ }^{6}$.

This hectic normative development is, moreover, of a much diversified character. Mirroring trends which had already been at the origin of the formidable development of International law at large, more broadly over the last seven decades, and which had led a leading scholar to adroitly proclaim the post-ontological hour of international law (Franck, 1995), it seems arguable that this progress has in general been happening by cross-fertilizing the traditionally rather impermeable body of international water law with other fields of international law ${ }^{7}$. This global trend towards the corpus iuris of international water law building bridges with other fields of international law - and namely, international environmental law, international law of human rights and international economic law - may therefore be summarily apprehended in three main substantive "friendships" or "leanings" of international water law, its newer value or teleological choices: A choice towards "naturalizing", "environmentalising" or "greening" international water law; a trend towards "humanizing" international water law or, more broadly, rendering it more inclusive; and, more recently, a leaning towards looking more attentively at water, and the international law which is related to it, through a more consciously economic angle.

\section{The Environmentalization of International Water Law}

The environmentalization of International Water Law passes firstly through the normative apprehension of the

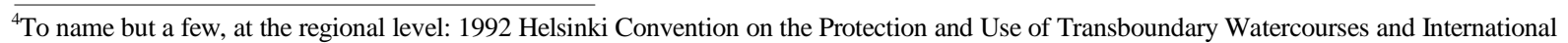
Lakes, 1991 Espoo Convention on Environmental Impact Assessment in a Transboundary Context, 1999 London Protocol on Water and Health, 2003 Protocol on Civil Liability and Compensation for Damages Caused by the Transboundary Effects of Industrial Accidents on Transboundary Waters, 1995 Protocol on Shared Watercourse Systems in the Southern African Development Community and its 2000 Revised Protocol on Shared Watercourses in the Southern African Development Community; and, at a local or specific basin level: 1994 Danube Convention on Cooperation for the Protection and Sustainable Use of the Danube River, 1994 Meuse and Scheldt agreements, revised in 2002, 1998 Convention between Portugal and Spain on the Cooperation for the Protection and Sustainable Use of the Waters of the Luso-Spanish River Basins, as well as the 2008 Revised Protocol to the Convention, 1999 Convention on the Protection of the Rhine, 1995 Agreement on the Cooperation for the Sustainable Development of the Mekong River Basin, 2002 Tripartite Interim Agreement between Mozambique, South Africa and Swaziland for the Cooperation on the Protection and Sustainable Utilisation of the Water Resources of the Incomati and the Maputo Watercourses, 2002 Senegal River Water Charter, 2003 Protocol for Sustainable Development of the Lake Victoria Basin. On the interplay and interactions between universal, regional and local basin instruments, see Boisson de Chazournes, 2009; Boisson de Chazournes, 2015.

${ }^{5}$ In 2003, the International Law Commission considered the area of the law applicable to transboundary groundwater resources and, in 2008, it adopted the Draft Articles on the Law of Transboundary Aquifers: UN Doc A/CN.4/L.724 (29 May 2008). See International Law Commission, Report of the International Law Commission -Fifty-eighth session, UN Doc A/61/10 (11 August 2006), pp. 183-245; International Law Commission, Report of the International Law Commission-Sixtieth session, UN Doc A/63/10 (8 August 2008); McCaffrey, 2009; Mechlem, 2009. Following up on this input, the UN General Assembly, by Resolution 66/104 of 31 January 2012, captioned "The Law of transboundary aquifers", has also encouraged "the States concerned to make appropriate bilateral or regional arrangements for the proper management of their transboundary aquifers, taking into account the provisions of the Draft Articles annexed to its Resolution 63/124”.

${ }^{6}$ To name but a few, see, in the International Court of Justice: Gabcikovo-Nagymaros Project (Hungary v Slovakia), Judgment, ICJ Reports 1977; Kasikili/Sedudu Island (Botswana v Namibia), Judgment, ICJ Reports 1999; Land and Maritime Boundary between Cameroon and Nigeria (Cameroon v Nigeria: Equatorial Guinea intervening), Judgment, ICJ Reports 2002; Frontier Dispute (Benin/Niger), Judgment, ICJ Reports 2005; Pulp Mills on the River Uruquay (Argentina v Uruguay), Provisional Measures, Order of 13 July 2006, ICJ Reports 2006; Pulp Mills on the River Uruguay (Argentina v Uruguay), Provisional Measures, Order of 23 January 2007, ICJ Reports 2007; Dispute Regarding Navigational and Related Rights (Costa Rica v Nicaragua), Judgment, ICJ Reports 2009; Pulp Mills on the River Uruguay (Argentina v Uruguay), Judgment, ICJ Reports 2010; Certain Activities carried out in the Border Area (Costa Rica v Nicaragua), Provisional Measures, ICJ Order of 8 March 2011; Frontier Dispute (Burkina Faso/Niger), Judgment of 16 April 2013; in the Permanent Court of Arbitration: Case concerning the audit of accounts between the Netherlands and France in application of the Protocol of 25 September 1991 Additional to the Convention for the Protection of the Rhine from Pollution by Chlorides of 3 December 1976 (Netherlands/France), Arbitral Award 2004; Indus Waters Kishenganga Arbitration (Pakistan v India), Order on Interim Measures 2011; Indus Waters Kishenganga Arbitration (Pakistan v India), Partial Award 2013; in the European Court of Justice. (a regional jurisprudence with international elements): Case 21/76 Handelskwekerij Bier v Mines de Potasse d'Alsace SA [1976] ECR 1735; Case C-36/98 Spain v Council of the European Union [2001] ECR I-00779; Case C-266/99 Commission of the European Communities v French Republic [2001] ECR I-2000; Case C-32/05 Commission of the European Communities v Grand Duchy of Luxembourg [2006] ECR I-11349.

${ }^{7}$ We have been arguing this since Canelas de Castro, 2005. See also, Canelas de Castro, 2008. 
reality of water bodies as it really happens: in its multiple interconnections and unitary complexity—of (nonconfined) groundwater with surface water ${ }^{8}$, of the watercourses with other biota and ecosystems ${ }^{9}$, with the land mass ${ }^{10}$ as well as with marine waters ${ }^{11}$. Several legal documents advocate that catchment areas or other analogous integrating concepts be used as the water management units ${ }^{12}$. This then permits and facilitates a more realistic or effective legal discipline: one where development of water is not any longer the sole goal pursued, but where instead development becomes integrated with the goal of protection of water ${ }^{13}$; one where, therefore, only sustainable development is lawful. Protecting the environment or ecosystems of watercourses, water quality, as well as the fight against diverse forms of pollution, thus become main concerns and normative areas of the newer international water legal disciplines ${ }^{14}$. Correspondingly, the scope of the obligations comprehended is equally enlarged: beyond obligations of mitigation and minimization or reduction and control of harm ${ }^{15}$-of risks ${ }^{16}$, even - there are now obligations of prevention of impacts, of precaution ${ }^{17}$. They all explain the consecration of procedural duties, ranging from notification of planned measures to consultations and negotiation ${ }^{18}$, from simple obligations of access to information to a general duty to perform environmental ${ }^{19}$ and strategic impact assessments, sometimes ex post even ${ }^{20}$. This wider approach becomes the more necessary as one acknowledges the crucial relevance of water in the ongoing conditions of scarcity ${ }^{21}$ and climate change ${ }^{22}$. Both realisations call for actions and measures ${ }^{23}$ that have a broader and cyclical time reference. These developments are in line with the concept of integrated water resources management as defined by the Global Water Partnership and based on the

\footnotetext{
${ }^{8}$ The very notion of watercourse as well as other key notions of these regimes comprehend and integrate different types of waters as well as other elements. On the other hand, it excludes confined waters and other elements, which are better apprehended through the notion of "hydrographic basin” or alike. This leads several Authors to criticize the approach: see Salman, 2005, and Brown-Weiss, 2007, who proclaims that "The 1997 UN International Watercourses Convention has several deficiencies from the water science perspective".

${ }^{9}$ For instance, in the United Nations Watercourses Convention, article 20.

${ }^{10}$ The notion of "hydrographic basin" apprehends better these interconnections. Whereas it is sometimes used in regional (e.g., African, see Kamto, 1990; see also the Water Framework Directive, in the European regional context) and local instruments, it was not retained in the UN Watercourses Convention, where the sovereignty sensitivities of States prevailed. See Paquerot, 2005; Sohnle, 2002; Coulée, 2011.

${ }^{11}$ E.g., in the Watercourses Convention, article 23, which constitutes a recognition that land-based pollution is also a source of maritime pollution. See Canelas de Castro, 2003.

${ }^{12}$ For instance, the 1998 Luso-Spanish Convention.

${ }^{13}$ This is explicitly reflected, for instance, in the very designation of conventions like the 1994 Danube Convention, the 1998 Luso-Spanish Convention, the 2002 Tripartite Interim Agreement relating to the Incomati and Maputo watercourses. In a different normative strategy, in the 1997 UN Watercourses Convention, protection of the watercourse has been recognized as a component of equitable and reasonable utilization-hence, articles 5, 6 (a) and (f). In addition, the 1997 Convention codifies a number of cooperation obligations that help to prevent or mitigate environmental damage. Moreover, its Part IV is dedicated to the protection, preservation and management of riverine ecosystems. Regionally, this is a marked difference between the Revised SADC Protocol, from 2000, and the first Protocol on Shared Watercourse Systems, adopted in 1995: e.g., the objectives listed in article 2 aim for sustainable, integrated and environmentally sound development and management.

${ }^{14}$ This is even more so in Europe and North America, sometimes as a response to catastrophes deriving from industrial accidents. See Kiss, 1987.

${ }^{15}$ E.g., Article 21 of the United Nations Watercourses Convention.

${ }^{16}$ This is one of the triggers of precaution. See Boisson de Chazournes, 2007; and Martin, 1998.

${ }^{17}$ For instance, the threshold for the due diligence obligations to prevent, reduce and control pollution also existing in the Watercourses Convention, has been raised in the 2008 Draft Articles on the Law of Transboundary Aquifers through a provision, article 12, which requires States to take a precautionary approach. The precautionary principle also features highly in the Helsinki Convention (article 2 (5) (b)) and underlies the whole 1999 UNECE Protocol to the Helsinki Convention, on Water and Health. Locally, it may be traced in basin treaties, like the 1998 Luso-Spanish Convention and the revised 2002 Meuse and Scheldt Agreements. The principle has also been mentioned in Pulp Mills on the River Uruguay (Argentina v Uruguay), Judgment, ICJ Reports 2010, para 164.

${ }^{18}$ See Part III of the United Nations Convention.

${ }^{19}$ Both article 12 of the UN Watercourses Convention and article 15 of the Draft Articles on Transboundary Aquifers mention that the obligation of notification of planned measures should inter alia be accompanied by the results of environmental impact assessments. There is actually a linkage between the obligation to provide information and the impact assessments: this is demonstrated by the International Court of Justice's consideration in the Pulp Mills case that the information transmitted must include a complete environmental impact assessment in order to assess the effects of a planned measure on the environment and that the notification must "take place before the State concerned decides on the environmental viability of the plan, taking due account of the environmental impact assessment submitted to it", Pulp Mills on the River Uruguay (Argentina v Uruguay), Judgment, ICJ Reports 2010, para 120.

${ }^{20}$ This was indicated already in the Gabcikovo-Nagymaros case and explicitly spelled out in the Pulp Mills on the River Uruguay (Argentina $v$ Uruguay), Judgment, ICJ Reports 2010, para 205: once operations of a project have started, continuous monitoring of its effects on the environment must be undertaken.

${ }^{21}$ See, very appropriately, Brown-Weiss, 2013.

${ }^{22}$ See Canelas de Castro, 2011.

${ }^{23}$ Like adaptation strategies designed to face the impacts of climate change. See article 4 (1)(e) of the United Nations Framework Convention on Climate Change, of 9 May 1992, UNTS 1771 (1994).
} 
1992 Dublin Statement on Water and Sustainable Development.

\section{The Humanization of International Water Law}

International Water Law has equally been witnessing a move towards including more legal personae within the remit of participating legal subjects.

This move concerns its traditional legal subjects, first: the States, the riparian States. Increasingly, the new international water law advocates that all those States, riparian to a particular shared watercourse, participate in the corresponding legal discipline ${ }^{24}$, thus matching at this level an effort at ensuring that the said legal discipline corresponds to reality, and that it therefore may prove more efficient. Moreover, in a few instances, international law equally calls on the participation of coastal States adjacent to the riparian ones ${ }^{25}$, in a legal development which again evidences an attention to natural reality and the real dynamics of impacts.

Secondly, the newer international water law equally concerns intergovernmental organizations and institutions of very different structures and functions ${ }^{26,27}$. Their establishment or revival ${ }^{28}$ reflects the perceived need of States to enhance cooperation to manage shared water resources over several territories ${ }^{29}$. Their existence facilitates the recurring dialogue between the riparian States as to the activities that each of them purports to promote within its jurisdiction, particularly with regard to the sharing of rights and benefits deriving from the development of the waters as well as the prevention, reduction and control of risks of damages. They especially allow for an institutional process of communication, made of different procedural acts which permit the assessment of the effects of planned or existing measures or projects ${ }^{30}$. Finally, they also enable the carrying out of joint activities.

Most noticeably, different legal instruments ${ }^{31}$ recommend that river/watercourse commissions be set up or that their experience is used ${ }^{32}$ in the daily effort of implementing but also developing primary regimes ${ }^{33}$. In some cases, international organizations or international commissions are equally called to complement the action of the States (by providing financial and technical assistance ${ }^{34}$, or working as instances for the prevention and settlement of disputes $\left.{ }^{35}\right)^{36}$.

Additionally, these organisations and institutions are sometimes also the platform for other non-governmental actors to intervene; like environmental, human rights’ or governance NGOs, as well as epistemic communities,

\footnotetext{
${ }^{24}$ See article 3 of the United Nations Convention.

${ }^{25}$ See article $9(3)$ of the Helsinki Convention.

${ }^{26}$ For an effort at designing a typology, see Caflisch, 1989; Boisson de Chazournes, 2003 underlines the emergence of a trend towards their harmonization, though; one which is induced partially by global and regional conventions which themselves promote the creation of basin organizations and commissions.

${ }^{27}$ Whereas the scope of cooperation in these organisations and commissions was narrow in the nineteenth century, it gradually broadened throughout the twentieth century in parallel with a movement of increased and more diversified use of the international rivers. The range of competencies of these organisations and commissions has equally become vaster. Whereas in the beginning their main task concerned navigation regulation, the scope was widened to cover activities like the production of energy, irrigation, recreational and environmental protection activities and include functions like those of information collection and dissemination, regulation by the adoption of standards and guidelines, the promotion and execution of joint operational activities, the brokering of discussions for the eventual development of other legal instruments. See exemplarily, the Luso-Spanish Convention, article 10.

${ }^{28}$ For early institutional experiences, see Chamberlain, 1923; Blociszewski, 1926; Colliard, 1968 ; McCaffrey, 2007.

${ }^{29}$ Similarly, Pulp Mills on the River Uruguay (Argentina v Uruguay), Judgment, ICJ Reports 2010, para 81.

${ }^{30}$ Their importance is stressed in the Pulp Mills on the River Uruguay (Argentina v Uruguay) Case, paras 115 and 119.

${ }^{31}$ Also scientific associations called for such legal and institutional developments: see for instance, Institute of International Law, "Resolution on the International Regulations regarding the Use of International Watercourses” of 1911.

${ }^{32}$ See article 3 (4) of the 2000 EU Water Framework Directive.

${ }^{33}$ This function of platform for legal development and implementation is clearly spelled out in the designation of the Luso-Spanish commission established by the 1998 convention. See also article 10 of the Convention, devoting a particular attention to the law-making potential of the commission.

${ }^{34}$ See Boisson de Chazournes, 2007 and, specifically on water, Boisson de Chazournes, 2015.

${ }^{35}$ The 1997 Convention on the Law of the Non-Navigational Uses of International Watercourses underlines such role in article 33(2). Different basin agreements, like the 1998 Luso-Spanish Convention and the 1909 Treaty on Boundary Waters, and Questions Arising between the United States and Canada (article IX) equally award this function to the corresponding commission, generally linking it to the object and purpose of the regime at stake.

${ }^{36}$ For which, the international legal personality of a river commission may be added value, particularly in relations with third actors. See article 11 of the 1995 Agreement on the Cooperation for the Sustainable Development of the Mekong River Basin which expressly states: "The institutional framework for cooperation in the Mekong River Basin (...) shall (....) enjoy the status of an international body, including entering into agreements and obligations with the donor or international community”.
} 
companies and individuals. All of them, thus thereby find their way to voice their concerns, grievances, interests, information, expertise ${ }^{37}$. Simultaneously, they obtain some legal status in the processes of decision-making or adjudicating the manifold issues of water management ${ }^{38,39}$.

The whole movement reaches its climax once international law engages into its humanization—firstly, by recognizing procedural rights of access to information ${ }^{40}$, participation in decision-making and in administrative decisions relating to the environment as well as the judicial appeal against such decisions, and rights of participation in impact assessments as well as in the aforementioned institutional water platforms. The 1998 Aarhus Convention on access to information, public participation in decision-making and access to justice in environmental matters ${ }^{41}$, in the UNECE universe, stands out in such context as a prominent illustration ${ }^{42,43}$.

The humanization of international water law is evidenced then, in the adoption of a human right to water and sanitation $^{44}$, which corresponds to the satisfaction of the most basic human needs ${ }^{45,46}$ and overcomes a blatant lacuna of the International Bill of Human Rights. Initiated with General Comment $n^{\circ} 15$ of the Economic and Social Council ${ }^{47}$, the process of consolidation ${ }^{48}$ of such double right gained momentum in 2010, by the adoption of corresponding resolutions by the General Assembly of the United Nations ${ }^{49}$ and the Human Rights Council ${ }^{50}$. These documents ${ }^{51}$ mainly anchor such right ${ }^{52}$ of multifaceted content ${ }^{53}$ in the remit of economic, social and

\footnotetext{
${ }^{37}$ With the "privatisation” of assistance ensuing from the 1992 Rio Conference, the Monterrey Conference, but especially the Johannesburg Summit, the private sector also helps in the financing of implementing projects and legal instruments-usually in partnerships between governments and civil society groups.

${ }^{38}$ See Mekong River Commission for Sustainable Development, 2005.

${ }^{39} \mathrm{~A}$ pivotal role is frequently played by these institutions' secretariats.

${ }^{40}$ See e.g., Sand, 2003.

${ }^{41}$ See McAllister, 1998.

${ }^{42}$ See United Nations Economic Commission for Europe, 2000.

${ }^{43}$ Similarly, in the African context, the African Convention on the Conservation of Nature and Natural Resources.

${ }^{44}$ See Albuquerque, 2013.

${ }^{45}$ The consideration of human needs in the development of international water law predates the recognition of the human right to water.

${ }^{46}$ It is important to realise that the human right to water and sanitation is linked to the satisfaction of personal and domestic needs, and thus to some privileged uses of water, in particular those related to household and personal uses. It therefore does not pertain to the whole spectrum of other usages, such as industrial, agricultural, fishing, navigation, hydroelectric uses or those related to the protection of the environment, irrespective of the close links existing among them. The fundamental rights nature of the right to water lends this right its objective priority status - as does the international law of watercourses with the provision of article 10 of the 1997 Watercourses Convention.

${ }^{47}$ General Comment No. 15 (2002) of the Economic and Social Council, “The Right to Water”, UN Doc E/C.12/2002/11 of 20 January 2010. ${ }^{48}$ Other milestones in the process, even prior to General Comment No. 15, are the UN Mar del Plata Action Plan of 1977, the Dublin Statement on Water and Sustainable Development of 1992 and Agenda 21. Also international treaties contribute to defining aspects or beneficiaries of this right: in particular, the Convention on the Elimination of All forms of Discrimination Against Women (article 14 (2)), the Convention on the Rights of the Child (article 24 (2)), the Convention on the Rights of Disabled Persons (article 28 (2a)). Equally noteworthy are the Draft Guidelines for the Realization of the Right to Drinking Water Supply and Sanitation adopted by the Sub-Commission on the Promotion and Protection of Human Rights, in 2005. Besides human rights instruments, also those relating to the law of international watercourses contributed to the emergence of the right: particularly, the Protocol on Water and Health, the Charter of Water of the Senegal River, the Water Charter of the Niger Basin and the Charter of Water of Lake Chad.

${ }^{49}$ Resolution 64/292 of the UN General Assembly, “The Human Right to water and sanitation”, UN Doc A/Res/64/292, of 3 August 2010.

${ }^{50}$ Resolution 15/L.14 of the Human Rights Council, "Human rights and access to safe drinking water and sanitation”, UN Doc A/HRC/15/L. 14 of 24 September 2010.

${ }^{51}$ Beyond the conceptual and even interpretative differences between the different normative instruments, as to the legal scope of the right, content, field of application and application (see Caflisch, 2011), they all recognize the importance of this right and share a vision or general objective: the one of achieving access to safe drinking for the human beings and obtaining access to sanitation systems. This objective mobilized legally and politically different actors and set the framework for seeking effective implementation and realization of this right, a formidable endeavor in view of the realities in the field (see WHO and UNICEF, 2010). In this latter regard, certain initiatives stand out for their contribution to the advancement of the aforementioned general objective: namely, the decision of the Human Rights Council in 2008 (by Resolution 7/22) to appoint an Independent Expert on the issue of Human Rights relating to access to drinking water and sanitation , who became in 2011 (by Resolution 16/2) the Special Rapporteur on the Right to safe drinking water and sanitation-it established the right to water and the reports of the Special Rapporteur helped refine the contents thereof (see Albuquerque, 2012); also noteworthy are the calls by the Human Rights Council for States to implement this right.

${ }^{52}$ Some instruments formulate this right as an autonomous right, while others link it to other rights and even make it derive therefrom: for instance, with the right to life and as a prerequisite for the realization of all human rights (e.g., Resolution 64/292 of the General Assembly), the right to an adequate standard of living and the right to the highest attainable standard of physical and mental health as well as the right to life and human dignity (Resolution 15/L.14 of the Human Rights Council). General Comment No. 15 also derives the human right to water from the right to an adequate standard of living and considers that it is "inextricably related to the right to the highest attainable standard of health and the rights to adequate housing and adequate food".
} 
cultural rights—a qualification, which renders these rights, ones of a progressive realization ${ }^{54}$. Be as it may, it equally implies a certain number of consequential obligations for the States, namely obligations to respect, protect and fulfill ${ }^{55}$. Amongst other duties, they call for the States' supplementary regulatory working. It is equally certain that the human right to water does not hinder the State to perceive payment for the services rendered. This applies, moreover, to not only the State but also other actors, which may, in particular, intervene in the provision of water services or waste treatment services ${ }^{56}$. This intervention seems justifiable: not only because the right is neutral as to the economic model adopted by the State as to such vital public services, but also because momentous investments seem indeed to be in order for rendering this proclaimed right a true reality. In any event, the interface between this right and a kind of water management more economically-driven is, doubtlessly, one of the areas where international water law may need further development and clarification.

\section{The Economicisation of International Water Law}

The third vector of renewal of international water law contends with the integration of the economy and its international legal disciplines. The departing point is parallel to the ones seen in regard to the aforementioned strands of evolution of this body of rules: besides being taken as an environmental good, and a pole for legally empowering a diverse host of actors, and particularly for accrediting human rights, water is also more and more apprehended as a commodity, as an economic good ${ }^{57}$.

This development is propitiated by several factors: the widespread awareness of water scarcity and unequal distribution ${ }^{58}$, leading to a mounting demand for the resource as well as a rising capacity to dispose thereof over time and space ${ }^{59}$.

Such developments then lead to elucubrations whether water or the service of its provision gains in being set in a market context ${ }^{60}$, attached a "rationalizing" price $\operatorname{tag}^{61}$. It is equally questioned whether there is merit in trading bulk water ${ }^{62}$ besides increasingly conveying it across space from "water-rich" to "water-poor" areas ${ }^{63}$, as well as collecting it from the natural milieu, bottling it and selling it in a growing market of water "products",64. This approach is epitomized in some policy documents from the nineties of last century, like the Agenda $21^{65}$, the Dublin Declaration ${ }^{66}$ or the World Water Vision of the World Water Council ${ }^{67}$.

Similarly, an apparently growing stream of legal thinking seems to be devoted to wondering whether there may be merit in applying international trade law (and the WTO agreements, GATT and GATS foremost) ${ }^{68}$ as well as international investment law (the myriad of regional agreements and BITs) ${ }^{69}$, as well as the corresponding institutions, to relevant water operations and what may be the consequences of such course of action.

More specifically, this rather creative or "outside-the-box" legal thinking is concerned, firstly, in regard to the

${ }^{53}$ The notes of equitable access, quality, availability, affordability are usually invoked in this regard. See Coulée, 2011 and Albuquerque, 2010.

${ }^{54}$ See article 2 (1) of the International Covenant on Economic, Social and Cultural Rights and Salman \& McInerney-Lankford, 2004.

${ }^{55}$ Idem, at pp. 67-68.

${ }^{56}$ More broadly, drawing a connection between the fight for this right and the ascension of new actors in the international scene and their claim for treating water as a global public good and for a global governance of water, see Coulée, 2011.

${ }^{57}$ Dealing with water as an economic good is one of the ways increasingly suggested in order to efficiently manage water. For instance, Dalhuisen, Groot, and Nijkamp, 2000 state that: "An economic approach to water supply and demand may contribute to a better management of water and to its sustainable use".

${ }^{58}$ Idem, p. 3.

${ }^{59}$ See Cossy, 2005a.

${ }^{60}$ Carter et al. (eds.), 1994; Anderson (ed.), 1994; Libecap, 2005.

${ }^{61}$ Cossy, 2005a; Hildering, 2005; Caponera, 1992.

${ }^{62}$ See Haan, 1997; Hildering, 2005.

${ }^{63}$ Examples quoted or discussed include the tender between Turkey and Israel, the export of water from Canada to the USA, the transfers between Malaysia and Singapore, Lesotho and South Africa, Mainland China to Hong Kong and Macau. See Cossy, 2005a; Hildering, 2005; Little, 1996; Baumann, 2001.

${ }^{64}$ Brown-Weiss, 2005.

${ }^{65}$ Chapter 18, para. 18.8 alludes to water as a social and economic good, namely when it states that "integrated water resources management is based on the perception of water as an integral part of the ecosystem, a natural resource and a social and economic good".

${ }^{66}$ Principle 4 of the Dublin Statement on Water and Sustainable Development states that "water has an economic value in all its competing uses and should be recognized as an economic good". On this, see Solanes, 1998.

${ }^{67}$ See Cossy, 2005a.

${ }^{68}$ See, in particular, Brown-Weiss, 2005; Cossy, 2005c; Tuerk, Ostrovsky, \&, Speed, 2005; Boisson de Chazournes, 2015.

${ }^{69}$ See the whole Chapter IV of Brown-Weiss, 2005; Boisson de Chazournes, Fresh Water in International Law, pp. 96-104; Bray, 2014. 
trading of bulk water products, whether water may be treated as a "good"70, a "product"71,72. It wonders, next, whether there is anything specific to water ${ }^{73}$, justifying, if not imposing, that these principles governing international trade be derogated (the principles of most favored nation, of non-discrimination) or instead that it compels certain water-rich countries to envisage exporting water resources in abundance ${ }^{74}$. Were the GATT disciplines deemed to be applicable ${ }^{75}$, another line of enquiry is what would the margin of maneuver for an exporting State mindful of the necessity to follow a precautionary approach in the management of its water resources be ${ }^{76}$, so as to avoid violating GATT obligations aiming both at reducing tariff barriers and quantitative restrictions on trade as well as to remove any national measure that discriminates against domestic products vis-à-vis imported products $^{77}$; whether in its managerial policies of environmental protection or driven by social considerations, such State could be comforted in the excepting clauses of Article XI. 2(a) and, particularly, Article XX of GATT ${ }^{78}$.

\footnotetext{
${ }^{70}$ This has to do with the fact that GATT applies to goods, a concept which is not defined but which seems to relate to a moveable thing which may be traded on a market.

${ }^{71}$ Again this is an undefined operational concept determining the application of the GATT disciplines. It implies that something is produced as a result of a natural process or human operation, human intervention. Another element of the definition is the one of the attribution of a price. See Haan, 1997; Cossy, 2005b.

${ }^{72}$ In a 2000 report on the Protection of Waters of the Great Lakes, the International Joint Commission between Canada and the United States stated expressly the view that water in its natural state is not a product or commodity. IJC, Final Report to the Government of Canada and the United States, Protection of the Waters of the Great Lakes, 2000. This view was reiterated in the 2004 report, where the International Joint Commission recommended that "both governments take steps to allay fears that Great Lakes water could be treated as a commodity" and again insisted on the idea that WTO rules do not affect the protection of water in its natural state. IJC, Review of the Recommendations in the February 2000 Report, Protection of the Waters of the Great Lakes, 2004.
}

${ }^{73}$ The condition of natural resource and the fact that so many social expectations are attached thereto are considerable elements in such debate. As the WTO concluded in the World Trade Report 2010 on trade in natural resources, "WTO rules were not specifically drafted to regulate natural resources trade and may not always respond adequately to the specific features of this sector". WTO, World Trade Report: Trade in Natural Resources, p. 203.

${ }^{74}$ The debate is particularly intense in regard to Canada. It explicitly involves the questioning whether the trade regimes of the WTO and in special the North American Free Trade Agreement (NAFTA) deny the right to limit water exports in respect of other members of the NAFTA and instead require the "water-rich State" to export its water as a tradable good, despite the risk that this poses to this State’s control over the management and preservation of the water resources. See Baumann, 2001; Maravilla, 2001; Anderson, 1999.

${ }^{75}$ Canada, the United States and Mexico have expressly addressed the issue of the application of NAFTA to water, in 1993, by making a joint statement which reads: "The NAFTA creates no rights to the natural resources of any Party to the Agreement (...). Water in its natural state in lakes, rivers, reservoirs, aquifers, water basins and the like is not a good or product, is not traded, and therefore is not and has never been subject to the terms of any agreement". Reprinted in Brown-Weiss, Boisson de Chazournes, \& Bernasconi-Osterwalder (eds.), 2005. On its one side, Canada insisted that water in the natural state should be excluded from the application of trade agreements, by having the Ministry of Foreign Affairs and International Trade, unilaterally declare that: "Water in its natural state can be equated with other natural resources, such as trees in the forest, fish in the sea, or minerals in the ground. While all of these things can be transformed into saleable commodities through harvesting or extraction, until that crucial step is taken they remain natural resources and outside the scope of the trade agreements". Department of Foreign Affairs and International Trade, "Paper on Bulk Water Removal and International Trade Considerations".

${ }^{76}$ Brown-Weiss calls a particular attention to the interplay of this approach and the uncertain long-term effects of climate change. See Brown-Weiss, 2005.

${ }^{77}$ Particularly at stake seem to be articles I (a water-exporting State would have to extend its "benefits" to any other State, so as not to violate the principle of most-favoured-nation treatment); III (a State that would be engaged in transfers, concerning water within its borders, would have to treat national and foreign competitors alike, for the national treatment principle); XI (although the rules on measures of export tariffs are less detailed than those on exports, its paragraph 2, in particular, seems to allow State water exporters to establish prohibitions or restrictions on transfers of bulk water "to prevent or relieve critical shortages or foodstuffs or other products essential to the exporting contracting party", such as droughts, effects of industrial accidents, natural disasters or other emergencies, these measures have to be temporary and only to prevent a critical situation); XX (setting the conditions for allowing States to implement national measures which, under certain conditions, are inconsistent with other provisions of GATT).

${ }^{78}$ In what concerns freshwater, the two openings or exceptions that seem to be relevant are those contained in sub-headings (b) and (g). Under the former, a State may maintain a measure otherwise inconsistent with other GATT provisions if that measure may be taken as "necessary to protect human, animal or plant life or health". In view of some case law concerning disputes before the Dispute Settlement Body of the WTO, it does not seem crucial that these actually versed on import restrictions on products-it seems possible for a State to argue for taking measures to restrict the export of water for environmental purposes and to protect the ecosystem of water resources: the State would thereby be seeking to protect human health and the preservation of flora and fauna. Additionally, to determine that a measure is "necessary" to achieve a specific goal, recourse must be made to the WTO case law: it indicates that the term "necessary" is not limited to meaning "indispensable" but also encompasses "promote". Moreover, it equally implies that the "common interests" and "shared values" pursued by the measure must also be taken into account. The protection and conservation of water seem to be a good example of such vital common interests. Under the latter, a State may adopt measures "relating to the conservation of exhaustible natural resources if such measures are made effective in conjunction with restrictions on domestic production or consumption". Since WTO case law indicates that "renewable" resources may fall under the concept of "exhaustible natural resource", there would not be a problem, it seems, in applying the notion and the provision under article XX (g) to water. For a measure adopted by a State to be justified under Article XX, it is still necessary to meet the requirements of the "chapeau" of this provision. In particular, domestic measures must not constitute "a means of arbitrary or unjustifiable discrimination between countries where the same conditions prevail, or a disguised restriction on international trade". At stake, in the very clarification made by WTO case law, is "rather the manner in which the measure is applied" (US-Gasoline, Report of the Appellate Body, para. 22. On Article XX’s “chapeau”, see Gaines, 2001. 
Equally, it is asked whether it would be sensible to depend on the adjudicatory mechanisms of the WTO dispute settlement system for pursuing such policies ${ }^{79}$.

In regard to water and wastewater services and the applicability of GATS, the main queries regard, besides classification issues $^{80}$, the possibility of carving out water public services in case of opening up the market to other foreign or domestic service providers ${ }^{81}$. Alternatively, it seems important to assess the usefulness of the reasons that article XIV of GATS provides, permitting derogations from the State's specific commitments, and, more largely, the extent of regulatory powers, which the host State may safeguard in the name of the pursuance of the public interest. Another provision with relevance is Article XIII of GATS, which sets out that the obligations of most favored nation treatment, market access and national treatment do not apply to "laws, regulations or requirements governing the procurement by governmental agencies of services purchased for governmental purposes and not with a view to commercial resale or with a view to use in the supply of services for commercial sale". If the contracts between public authorities and private water companies can be characterized as "government procurement", then the GATS regime (the obligations of most favored-nation, market access and national treatment) does not apply either ${ }^{82}$. It does not seem, however, that the concession contracts or build-operatetransfer contracts that are frequently used for ensuring water services should be considered public procurement ${ }^{83}$.

In substantive connection to such debate, albeit not in terms of the legal instruments at stake, appear the discussions on investment solutions in the water sector. They derive from the apparent growing recognition of the financial crisis of the State. This financial crisis leads the State to rethink the priorities and engagement in the economic sector and, in particular, in the water area, towards catering technical expertise and financial assets through multiple forms of privatization of services which had previously axiomatically been seen as publicnamely by engaging sometimes very powerful multinational enterprises willing to offer such services on an economic profit logics; as it drives the State to opening up to foreign direct investment, usually protected by the body of rules of international investment law and its mechanisms of dispute settlement, often relying on international arbitration. In spite of its close proximity, whereas the former debate on market liberalization systematically pertains to WTO law instruments and the GATS regime in particular ${ }^{84}$, this latter one, for the lack of an investment dimension in the WTO agreements, rather has its systemic legal "seat" in the area related to the hundreds of regional and bilateral investment treaties.

The main issue debated relates to the host State's regulatory powers in view of the obligations to protect international investment and the mechanisms for the State to protect public interest in regard to private sector participation in the economic management of water. The effort is at striking the right balance between the powers seeking the protection of public interest and serving corresponding obligations like those correspective of a human right to water or those related to the protection of the environment, on the one hand, and those directed at the protection of international investments, on the other hand. A number of awards through ICSID dispute settlement ${ }^{85}$ may be viewed as indicative of progress in such direction ${ }^{86}$.

\section{Concluding Remarks}

The protrayed newer leanings or trends of development of international water law reveal an effort at holistically

\footnotetext{
${ }^{79}$ It would appear that disputes about the allocation and use of water, as well as about the legitimacy to protect ecosystems and the ecology would be made by bodies more prepared for and attuned to trade considerations. Discussing this issue as other "reasons not to apply the GATT 1994 to water in its natural state or to bulk transfers", see Brown-Weiss, "Water Transfers and International Trade Law", in Brown-Weiss, 2005.

${ }^{80}$ Like the harmonized system of GATT relating to products, there is a classification list of services set by the WTO Secretariat, which is not mandatory but used by States to develop schedules of commitments in the liberalisation of markets. It does not contain any separate category for services related to water, but some of the sectors considered do contain references to activities related to water, like environmental services and sanitation, for instance.

${ }^{81}$ The question is whether it is possible to argue that these water services fall under the provision of article I:3(b) which establishes that "services supplied in the exercise of governmental authority" are excluded from the scope of the GATS. These are defined as being supplied "neither on a commercial basis, nor in competition with one or more suppliers". The thorny issue is the determination of the relationship between "public service" and "governmental authority": they can certainly not be interpreted as synonymous. It might equally be possible to argue that services of water distribution stand as a public monopoly. In such case, GATS would apply.

${ }^{82}$ Cossy, 2005a.

${ }^{83}$ Cossy, 2005b.

${ }^{84}$ GATS does not mention privatization or demand that the water services suppliers are public or private-article XXVIII does not indicate any preference.

${ }^{85}$ Namely, in the Aguas del Tunari v Bolivia ICSID Case No. ARB/02/3, in the Suez, Sociedad General de Aguas de Barcelona SA and Vivendi Universal SA v Argentine Republic ICSID Case No ARB/03/19, in the Biwater Gauff (Tanzania) Ltd v United Republic of Tanzania ICSID Case No ARB/05/22, and in the Azurix Corp v Argentine Republic, ICSID Case No ARB/01/12.

${ }^{86}$ Bray, 2014.
} 
apprehending and giving normative response to a more complex reality of problems and social expectations than those that used to be addressed by the old international water law, centered on the pure regulation of the uses of water. The changes involved are diverse and numerous. It seems however possible to identify some common threads underlying all the changes and trends identified. A first one is the move towards establishing a creative interface between the traditional core of this body of principles and rules dedicated to water and those other disciplines of international law which more directly address the concerns with the protection of the environment, social equity, and a sensible weighing of the economic values. Internormativity is thus one of the keys for understanding the evolution of international water law and the vigor thereof; the normative dialogue generates cross-fertilisation and renovation of international water law. Another one is the implicit sense of urgency that these proposed changes and trends carry, corresponding only to the magnitude of the global water crisis. These changes are definitely momentous, as the newer law became much more complex in the normative responses pursued. They are not however deprived of an underlying vision: on the contrary, the newer international water law announces decisive cardinal options, pursues shared goals, honours certain values, follows principles which lend heuristic and interpretative sense to the reconstruction of this legal field. In the whole, the changes thus amount to true paradigm-shifts (Kuhn, 1962). But this realisation also alerts us to the uncertainties that are still involved in the progress of international water law. It is of the very nature of paradigm-shifts themselves that they comprehend ambiguities and even elicit resistance. The uncertain harmonisation of the trends for environmentalisation and humanisation of water, on the one hand, and its economicisation, on the other, is in this regard telling. To this, one should add the realisation that these developments are an ongoing process: new problems seem already perceptible in the horizon- “climatising” international water law, adapting it to the challenges of climate change seems to be one of them. Another one is the struggle to render the whole movement of "legalisation” or more and newer law-making, a living reality: ensuring that the newer normative messages are complied with, should also become one of the major tenets of the evolution of international water law. Assessing the past but also looking ahead, one can not but be reminded of the works of Sisyphus.

\section{References}

Albuquerque, C. (2010). Water and Sanitation as Human Rights. In Conseil d'Etat, L'eau et son droit, Rapport publique. Paris: Conseil d'état.

Albuquerque, C. (2012). On the Right Track: Good Practices in Realising the Rights to Water and Sanitation. New York: The United Nations.

Albuquerque, C. (2013). Water and Sanitation Are Human Rights: Why Does It Matter? In L. Boisson de Chazournes, C. Leb, \& M. Tignino, (Eds.). International Law and Freshwater: The Multiple Challenges. Cheltenham: Edward Elgar. http://dx.doi.org/10.4337/9781781005095.00013

Anderson, B. D. (1999). Selling Great Lakes Water to a Thirsty World: Legal, Policy and Trade Considerations. Buffalo Environmental Law Journal, 6, 219-220.

Anderson, T. L. Eds. (1994). Continental Water Marketing. San Francisco: Pacific Research Institute for Public Policy.

Baumann, C. (2001). Water Wars: Canada's Upstream Battle to Ban Bulk Water Export. Minnesota Journal of Global Trade, 10.

Blociszewski, J. (1926). Le régime international du Danube. Recueil des Cours de l'Académie de La Haye, 11, 253-340. http://dx.doi.org/10.1163/ej.9789028604827.253-340

Bogdanovic, S. (2001). International Law of Water Resources: Contribution of the ILA (1954-2000). London: Kluwer.

Boisson de Chazournes, L. (2003). The Role of Diplomatic Means of Solving Water Disputes: A Special Emphasis on Institutional Mechanisms. In The PCA/Peace Palace Papers. Resolution of International Water Disputes (Vol. 5, pp. 91-110). The Hague: Kluwer.

Boisson de Chazournes, L. (2007). Precaution in International Law: Reflection on its Composite Nature. In T. M. Ndlaye et al. (Eds.). Law of the Sea, Environmental Law and Settlement of Disputes: Liber Amicorum Judge Thomas A. Mensah (pp. 21-34). Leiden: M. Nijhoff. http://dx.doi.org/10.1163/ej.9789004161566.i-0.22

Boisson de Chazournes, L. (2007). Technical and Financial Assistance. In D. Bodansky, J. Brunnée, \& E. Hey (Eds.), The Oxford Handbook of International Environmental Law (pp. 947-973). Oxford: Oxford University Press.

Boisson de Chazournes, L. (2009). Freshwater and International Law: The Interplay between Universal, Regional and Basin Perspectives. Paris: UNESCO, United Nations World Water Assessment Programme.

Boisson de Chazournes, L. (2015). Fresh Water in International Law. Oxford: Oxford University Press. 
Bray, H. L. (2014). ICSID and the Right to Water: An Ingredient in the Stone Soup. ICSID Review, 1-10.

Brown-Weiss, E. (2005). Water Transfers and International Trade Law. In E. Brown-Weiss, L. Boisson de Chazournes, \& N. Bernasconi-Osterwalder (Eds.), Fresh Water and International Economic Law (pp. 61-89). Oxford: Oxford University Press.

Brown-Weiss, E. (2007). The Evolution of International Water Law. Recueil des cours de l'académie de Droit international, 331, 222.

Brown-Weiss, E. (2013). International Law in a Water Scarce World. The Hague Academy of International Monographs, Volume 7, Leiden: Brill.

Brown-Weiss, E., Boisson de Chazournes, L., \& Bernasconi-Osterwalder, N. (Eds.) (2005). Fresh Water and International Economic Law. Oxford: Oxford University Press.

Caflisch, L. (1993). Sic utere tuo ut alienum non laedas: Règle prioritaire ou élément servant à mesurer le droit de participation équitable et raisonnable à l'utilisation d'un coursd'eau international? In A. Ziegler (Ed.), Internationales Recht auf See und Binnengewaesser. Festschrift fuer Walter Mueller (pp. 27-47). Zuerich: Schulthess.

Caflisch, L. (2011). Le droit à l'eau—Un droit de l’homme internationalement protégé. In Société française pour le droit international, Colloque d'Orléans. L'eau en droit international (pp. 392-394). Paris: Pédone.

Caflisch. L. (1989). Règles générales du droit des cours d'eau internationaux. Recueil des Cours de l'Académie de La Haye, 219, 196-202. http://dx.doi.org/10.1163/ej.9780792321408.009-225

Canelas de Castro, P. (2003). Freshwaters-Sea Interface: Emerging International Legal Field? Boletim da Faculdade de Direito da Universidade de Macau, 16, 179-220.

Canelas de Castro, P. (2005). Recent Developments in International Law. Principles and Comparative Cases. Lisbon: Luso-American Foundation.

Canelas de Castro, P. (2008). The Global Challenge of Sustainable Water Management: International and European Union Law Responses. Temas de Integração, 25, 95-133.

Canelas de Castro, P. (2011). Climate Change and Water Management: Is Water Law Adapted to Climate Change? In C. A. Brebbia, \& V. Popov (Eds.), Water Resources Management VI (pp. 827-839). Southampton: WIT Press.

http://dx.doi.org/10.2495/WRM110741

Caponera, D. (1992). Principles of Water Law and Administration. Rotterdam: A. A. Balkema.

Carter, H. O. (Ed.) (1994). Sharing Scarcity: Gainers and Losers in Water Marketing. Davis: University of California Agric. Issue Center.

Chamberlain, J. P. (1923). The Regime of the International River: Danube and Rhine. New York: Columbia University.

Colliard, C. A. (1968). Evolution et aspects actuels du régime juridique des fleuves internationaux. Recueil des Cours de l'Académie de La Haye, 125, 417-431. http://dx.doi.org/10.1163/ej.9789028616226.337-442

Cossy, M. (2005a). Le statut de l'eau en droit international économique. Principaux aspects au regard des règles de l’Organisation mondiale du commerce, In L. Boisson de Chazournes, \& S. M. A. Salman (Eds.), Les ressources en eau et le droit international (pp. 177-178). Leiden: Martinus Nijhoff.

Cossy, M. (2005b). Water Services and the GATS-Selected Legal Issues. In E. Brown-Weiss, L. Boisson de Chazournes, \& N. Bernasconi-Osterwalder (Eds.), Fresh Water and International Economic Law (pp. 129). Oxford: Oxford University Press.

Cossy, M. (2005c). Water Services at the WTO—Selected Legal Issues. In E. Brown-Weiss, L. Boisson de Chazournes, \& N. Bernasconi-Osterwalder (Eds.), Fresh Water and International Economic Law (pp. 117-141). Oxford: Oxford University Press.

Coulée, F. (2011). Rapport général—Du droit international de l'eau à la reconnaissance internationale d'un droit à l'eau: Les enjeux. In Société française pour le droit international, Colloque d'Orléans. L'eau en droit international (pp. 27-31). Paris: Pédone.

Dalhuisen, J. M., Groot, H. L. F., \& Nijkamp, P. (2000). The Economics of Water: A Survey. International Journal of Development Planning Literature, 15, 4.

Franck, T. (1995). Fairness in International Law and Institutions. Oxford: Clarendon Press.

Gaines, S. (2001). The WTO’s Reading of the GATT Article XX Chapeau: A Disguised Restriction on Environmental Measures. Journal of International Economic Law (University of Pacific), 22, 739.

Haan, E. (1997). Balancing Free Trade in Water and the Protection of Water Resources in GATT. In E. P. Brans et al. (Eds.), The Scarcity of Water-Emerging Legal and Policy Responses (pp. 246-247). The Hague: Kluwer.

Hildering, A. (2005). Water as an Economic Good. In L. Boisson de Chazournes, \& S. M. A. Salman (Eds.), Les ressources en eau et le droit international (pp. 225-227). Leiden: Martinus Nijhoff. 
http://dx.doi.org/10.1163/ej.9789004137028.3-756.6

Kamto, M. (1990). Le droit international des ressources en eau continentales africaines. Annuaire français de droit international, 36, 855-871.

Kiss, A. (1987). Tchernobâle ou la pollution accidentelle du Rhin par des produits chimiques. Annuaire français de droit international, 33, 719-727. http://dx.doi.org/10.3406/afdi.1987.2804

Kuhn, T. S. (1962). The Structure of Scientific Revolutions. Chicago: University of Chicago Press.

Libecap, G. D. (2005). Rescuing Water Markets: Lessons from Owens Valley. Bozeman: PERC.

Little, S. P. (1996). Canada's Capacity to Control the Flow: Water Export and the North American Free Trade Agreement. Pace International Law Review, 8, 127.

Manner, E., \& Metsalampi, V. M. (Eds.) (1988). The Work of the International Law Association on the Law of International Water Resources. Helsinki: Finnish Branch of the International Law Association.

Maravilla, S. (2001). The Canadian Bulk Water Moratorium and Its Implications for NAFTA. Current International Trade Law Journal, 10, 31-35.

Martin, G. J. (1998). Le concept de risque et la protection de l’environnement: Evolution parallèle ou fertilization croisée? In M. Prieur (Ed.), Les hommes et l'environnement, en hommage à Alexandre Kiss (pp. 451-460). Paris: Frison-Roche.

McAllister, S. T. (1998). The Convention on Access to Information, Public Participation in Decision-Making, and Access to Justice in Environmental Matters. Colorado Journal of International Environmental Law and Policy, 9, 187.

McCaffrey, S. (2007). The Law of International Watercourses-Non-Navigational Uses (2nd ed.). Oxford: Oxford University Press.

McCaffrey, S. (2009). The International Law Commission Adopts Draft Articles on Transboundary Aquifers. American Journal of International Law, 103, 272. http://dx.doi.org/10.2307/20535150

Mechlem, K. (2009). Moving Ahead in Protecting Freshwater Resources: The International Law Commission’s Draft Articles on Transboundary Aquifers. Leiden Journal of International Law, 22, 801. http://dx.doi.org/10.1017/S0922156509990239

Mekong River Commission for Sustainable Development (2005). Public Participation in the Lower Mekong Basin. Vientiane: Mekong River Commission for Sustainable Development.

Paquerot, S. (2005). Eau douce: La nécéssaire refondation du droit international. Sainte-Foy (Québec): Presses de l’Université du Québec.

Salman, S. M. A. (2005). Evolution and Context of International Water Resources Law. In S. M. A. Salman, \& L. Boisson de Chazournes (Eds.), Les ressources en eau et le droit international (pp. 66-68). The Hague: Hague Academy of International Law. http://dx.doi.org/10.1163/ej.9789004137028.3-756.2

Salman, S. M. A., \& Lankford, S. M. (2004). The Human Right to Water. Legal and Policy Dimensions. Washington DC: The World Bank. http://dx.doi.org/10.1596/0-8213-5922-3

Sand, P. H. (2003). Information Disclosure as an Instrument of Environmental Governance. Heidelberg Journal of International Law, 2, 487-502.

Sohnle, J. (2002). Le droit international des ressources en eau douce: Solidarité contre souveraineté. Paris: La documentation française.

Solanes, M. (1998). Integrated Water Management from the Perspective of the Dublin Principles. CEPAL Review, 64, 165.

Tanzi, A., \& Arcari, M. (2001). The United Nations Convention on the Law of International Watercourses: A Framework for Sharing. The Hague: Kluwer.

Tuerk, E., Ostrovsky, A., \& Speed, R. (2005). GATS and Its Impact on Private Sector Participation in Water Services. In E. Brown-Weiss, L. Boisson de Chazournes, \& N. Bernasconi-Osterwalder (Eds.), Fresh Water and International Economic Law (pp. 143-172). Oxford: Oxford University Press.

United Nations Economic Commission for Europe (2000). The Aarhus Convention: An Implementation Guide. New York: United Nations.

WHO and UNICEF (2010). Progress on Sanitation and Drinking Water: 2010 Update. Geneva: WHO and UNICEF.

Ziegler, A. (Ed.) (1993). Internationales Recht auf See und Binnengewaesser. Festschrift fuer Walter Mueller. Zuerich: Schulthess. 